\title{
A Study on the Implementation of U-G-S Collaborative Training Mode for Outstanding Teachers in Local Colleges and Universities
}

\author{
Linzi Qin $^{\dagger}$, Naizhu Huang ${ }^{\dagger}$, Lanyan Qin* \\ Xiangnan University, Chenzhou, Hunan, 423000, China \\ *Corresponding author. \\ $\uparrow$ The first two authors contributed equally to this paper and should be considered co-first authors.
}

\begin{abstract}
To train Excellent teachers, local universities should abandon the "university-led" training model, actively connect local governments and primary and secondary schools, and build a "three-in-one" collaborative training model for local universities $(U)$, local governments $(G)$, and primary and secondary schools $(S)$. The $U-G-S$ co-cultivation mode operates mainly with the following countermeasures: Local universities and local education administrative departments sign a strategic framework cooperation agreement, and carry out all-round cooperation around the cultivation of excellent teacher in the teacher profession; Local universities and local education administrative departments cooperate to build a basic education research institution, and promote the deep integration of theory and practice around the subject research; Local universities and primary and secondary schools cooperate to build Industry-University-Research collaborative platform and construct a whole-course practical teaching system, which include teaching observation, teacher's moral experience, teaching and research practice, case teaching, subject discussion, and inquiry reflection to improve the quality of training talents in normal education; Local universities cooperate and primary and secondary schools cooperate to build a famous teacher studio, fully using the role of famous teachers in the cultivation of Excellent teacher.
\end{abstract}

Keywords: Local universities; Excellent teacher; $U-G-S$ collaborative training mode

\section{Introduction}

Teachers are the foundation of education. Teachers shoulder the historical mission of spreading knowledge, ideas and truth, and the responsibility of shaping souls and lives. To accelerate the modernization of education in our country and provide higher quality, more equitable, distinctive and dynamic education for 1.3 billion people, our country has successively issued the "Opinions of the Central Committee of the Communist Party of China on Deepening the Reform of Teacher Construction in the New Era" "Opinions of the Ministry of Education on the Implementation of Excellent Teacher Training Program 2.0"Action Plan for Teacher Education Promotion (2018-2022), which requires normal universities and other teacher education institutions to strive to cultivate a team of high-quality, professional and innovative teachers with profound educational feelings, solid professional foundation, the courage to innovate in teaching, the ability to comprehensively educate and the ability to develop lifelong learning through the comprehensive reform of education. Comprehensive education reform has become the focus of our country's current education reform, and the key to promoting education reform and improving the quality of talent cultivation lies with teachers. Fundamentally speaking, teachers are the grassroots forces that affect the comprehensive reform of education.[1] Most of the local colleges and universities which are formed from the merger of the former normal colleges and other specialized science schools are located in prefecture-level cities whose mission is to train excellent teachers to serve the reform and development of regional basic education. To implement the spirit of national and provincial education conferences, according to the Ministry of Education's "Opinions on Accelerating the Construction of High-Level Undergraduate Education and Comprehensively Improving Talent Cultivation Ability" and "Several Opinions of the State Council General Office on Deepening the Integration of Industry and Education", The training of excellent teachers in local colleges and universities should

ISSN: 0010-8189

C CONVERTER 2020

www.converter-magazine.info 
focus on solving the "theoretical and practical problems in talent training", [2]Committing to cultivating the core qualities and abilities of normal students, and cultivating high-quality professional and innovative teachers.

\section{Components of Core Qualities and Abilities of Excellent Teacher}

Teacher education is the mother machine of education and the source of power to improve the quality of education[3]. At the national education conference, General Secretary Xi Jinping points out that the construction of teachers should be taken as the basic work, because the quality of teachers directly affects the quality of students' training and quality improvement. The Ministry of Education's "Opinions on Implementing Excellent Teacher Training Program 2.0" states that "by 2035, the comprehensive quality, professional level and innovative ability of normal university students will be significantly improved, which will lay a solid foundation for the training and training of millions of backbone teachers, hundreds of thousands of excellent teachers and tens of thousands of educators"[4]. Excellent teachers are the first resource to promote higher quality and more equitable education, and the training of excellent teachers is the obligatory responsibility of local colleges and universities to realize the Chinese dream of national rejuvenation. How can local colleges and universities train hundreds of thousands of excellent teachers? First, they need to seriously study and practice "Opinions on the Implementation of Excellent Teacher Training Plan 2.0"; Second, they need to devote themselves to studying the core quality and ability components of excellent teachers and the cultivation mechanism.

What are the core qualities and abilities of excellent teachers? Professor Guangming Wang of TianJin Normal University put forward the theory of "four-dimensional structure" of excellent teachers' core quality and ability through in-depth research[5]. The four dimensions of core literacy are political literacy (political orientation, political awareness, political belief), moral literacy (professional ethics, mental health), cultural literacy (humanistic literacy, scientific literacy, professional literacy, information literacy), and educational spirit (educational ideal, educational belief, and educational emotion). Core competence of four dimensions: education teaching ability (including teaching design ability, teaching ability, classroom management, teaching evaluation, curriculum development, ability), teaching research and innovation ability (including teaching research ability, innovation ability), learning and reflection ability (including self-cognition ability, reflection ability, continuous learning ability), communication and cooperation ability (communication and communication ability, collaborative cooperation ability). The traditional method of core literacy and ability cultivation of excellent teachers is a university-led model, with more educational theory and professional knowledge learned, and insufficient teacher skills and practical ability; in particular, high-quality educational resources in primary and secondary schools cannot be effectively used, and theory and practice are seriously out of touch. What's more, after the popularization of higher education, the pursuit of a large and comprehensive subject professional structure has weakened teacher education, resulting in insufficient focus on the training of normal students, and outstanding students are reluctant to enter teacher professional learning and other issues, resulting in a lack of teacher core literacy and ability, make it difficult to achieve the goal of training excellent teachers. To this end, China has launched a government-funded normal university student education policy to attract outstanding middle school students to study in the normal major, and issued the "Opinions on the Implementation of Excellent Teacher Training plan 2.0" to encourage colleges and universities to adopt the U-G-S "trinity" model to jointly train excellent teachers.

\section{The U-G-S Collaborative Model of Excellent Teachers' Core Literacy and Ability Training}

The traditional "university-led" teacher training model has led to the lack of local government , primary and secondary schools in teacher training and dereliction of duty, the separation of normal students' professional knowledge and practice, causing the failure to form core qualities and abilities. Therefore, guided by Xi Jinping's socialism with Chinese characteristics in the new era, on the basis of fully carrying out the fundamental task of cultivating people with morality, local colleges and universities should change the malpractice of the traditional teacher-training model, and highlight the value and status of the practical knowledge in teacher training, focus on

ISSN: 0010-8189

(C) CONVERTER 2020

www.converter-magazine.info 
solving the problem of the disconnection between theory and practice in teacher training, and build a U-G-S collaborative model in which local universities, local governments, and primary and secondary schools jointly shoulder teacher training responsibilities on the basis of equal cooperation through comprehensive education reform. The advantage of the collaborative training model is that it connects two long-separated parts of the teacher education process: educational theory and educational practice.[6] In order to give full play to the main role of local government (G) and primary and secondary schools (S) in teacher training, local colleges and universities (U) should be based on the needs of the new era of basic education reform and practice, taking the overall education development concept and the concept of "integrated teacher education" as Guidance, following the principles of "consistent goals, responsibility sharing, benefit sharing, and cooperative development", cooperating with local governments and primary and secondary schools, by integrating teacher education resources, negotiating teacher education programs, sharing teacher education responsibilities, participating in teacher education processes, and sharing teacher education achievements and other methods to jointly build a high-quality training system for teacher education. The high-quality training system emphasizes that local colleges and universities are the mainstay and responsible for the overall arrangements of education resources of local governments and primary and secondary schools to form a new teacher education community. Local governments provide maximum human, financial, business, and policy support for the training of normal professional talents; primary and secondary schools provide strong support for the training of normal professional talents in areas such as professional cognition, curriculum development, classroom teaching, apprenticeship and internship, and graduation design guidance. Local colleges, local governments, and primary and secondary schools have become trainers of "shared responsibility" and facilitators of "synergy development" for excellent teacher training, and strive to make their own contributions to the training of excellent teachers.

\section{Implementation Strategy of U-G-S Collaborative Mode for Core Competence and Ability Training of Excellent Teachers}

How does the U-G-S collaborative model of excellent teacher training work? "Cooperation and Practice" of "Secondary Education Professional Certification Standard (Level 3)" states: "Local colleges and universities should establish a " trinity "collaborative training mechanism with clear authority, responsibility, coordination, and win-win cooperation with local education administration departments and middle schools, collaboratively formulating training goals, designing curriculum systems, building curriculum resources, organizing teaching teams, and building practice base, Carrying out teaching research, evaluating training quality to form a cooperative community that integrates teacher training, training, research, and services. " In December 2014, the General Office of the Ministry of Education issued the "Notice on the Announcement of the Reform Project of Excellent Teacher Training Program" (The Teacher Office [2014] No. 5), showing that a large number of schools that have acquired outstanding middle school teacher training reform projects are directly related to the collaborative training of outstanding middle school teachers by universities, governments, and middle schools. [7] Local colleges and universities should follow the professional certification concept and adopt the following four countermeasures to run the U-G-S collaboration model.

\subsection{Local universities and local educational administrations sign strategic framework cooperation agreements}

Local colleges and universities should take the opportunity of setting up experimental areas for teacher education reform and take the initiative to dock with local education administration departments, signing strategic framework cooperation agreements around excellent teacher training, building a "trinity" collaborative training system for local colleges, local governments, and primary and secondary schools, and set up a three-subject collaborative education platform for local universities, local governments, and primary and secondary schools. The signing of the strategic framework cooperation agreement follows the principle of "full cooperation, highlighting key points, seeking practical results, pursuing innovation, and mutual benefit", and the two parties mainly focus on teacher professional training objectives, training programs, curriculum settings, resource construction, teaching

ISSN: 0010-8189 
teams, practice bases, post-service Cooperation in training, teaching and research, and quality evaluation. The two sides negotiate to establish a communication and coordination leadership group to promote cooperation in an all-round way. The communication and coordination leadership group includes: the deputy mayor of the local government in charge of education and the secretary of the party committee of local universities as advisor, the director of local education and the President of local university as team leaders, the eputy director of the local education bureau in charge of teacher work and the deputy principals in charge of development planning, teaching, and enrollment and employment in local universities as deputy head, the heads of relevant departments of local education bureaus, principals of primary and secondary schools in the domain, heads of relevant departments and teaching units of local colleges and universities as team members. The coordination office of the local education bureau is located in the department of teacher work and teacher education, and the coordination office of local universities is located in the planning and development department. Regular seminars for teacher training are held in mid-March every year to provide suggestions for the cultivation of excellent teachers.

\subsection{Local universities and local educational administrations cooperate to build basic education research institutions}

The training of excellent teachers requires a team of full-time and part-time teachers with high professional standards and strong educational and scientific research capabilities. Local colleges and universities must formulate preferential policies to introduce and train high-quality talents to undertake the teaching tasks of normal education, and also build a development platform for normal education to support the development of education and teaching research in primary and secondary schools, and strive to build high-quality innovative teaching teams. To this end, local universities and local education administration departments cooperate to build a basic education research institution to provide a research platform for full-time and part-time teachers in normal schools. Research institution funds are continuously provided by local colleges and universities, including office funds and project funds. Office funds are mainly used for the purchase of office supplies, newspapers and magazines, and expenses for holding academic conferences. The project funds are mainly used for project management and project research. The project research is organized by basic education research institutions to compile project guides around the cultivation of excellent teachers. And teachers of local colleges and universities and teachers in primary and secondary school teachers form teams to jointly declare and carry out research, which aims to improve the education and scientific research level and teaching ability of full-time and part-time teachers of teachers and teachers.

4.3 Local universities and primary and secondary schools cooperate to build an industry-university-research cooperation platform

"Base Construction" of "Secondary Education Professional Certification Standards (Level 3)" states: "It is necessary to build a long-term and stable educational practice base which has a good school spirit, strong teacher strength, subject advantages, management advantages, curriculum resources advantages and teaching reform practice advantages. No less than one educational practice base for every 20 interns, of which, no less than one-third is a model educational practice base." The government has no clear policy incentives, requirements, and system guarantees for collaborative research between universities and primary and secondary schools. Therefore, the cooperation between universities and primary and secondary schools is still in the form of individualized and spontaneous cooperation between colleges and universities. [8] To this end, all majors of teacher education in local colleges and universities should take the initiative to connect with primary and secondary schools, and jointly build an industry- university-research cooperation platform in accordance with the principle of "dual-subject" education between schools and schools, building a full-process practical teaching system including teaching observation, teacher's moral experience, teaching and research practice, class management practice, case teaching, theme discussion, inquiry reflection, etc. through the platform, scientifically allocating education apprenticeships, education internships, and education research sciences to the whole process of teacher training, and implement a "dual mentor" system in which local college teachers and excellent primary and secondary school teachers jointly guide education internships; carrying out in-depth cooperation in talent training, subject research, education 
innovation, social services, cultural inheritance, etc. through the platform, and attract excellent teachers from primary and secondary schools to participate in professional education reform practices, including professional planning, textbook development, teaching design, curriculum setting, and practical training Etc., to promote the integration of the needs of primary and secondary schools into the training of talents, and to improve the quality of normal education professionals. In addition, the industry-university- research cooperation platform can also play a guiding role in the following two aspects.

\subsubsection{Elementary and secondary school teaching research institutions}

Local university education research experts and scholars guide elementary and middle school teaching and research institutions to carry out their work through the industry-university-research platform, to help to formulate elementary and middle school teaching research systems and professional development plans for elementary and middle school teachers, to create a good teaching and academic atmosphere for elementary and middle schools, and to organize elementary and middle school teachers to carry out teaching research, academic evaluation of teaching, teaching skill competition, etc., jointly promoting the professional development of primary and secondary school teachers. Teacher Professional Development Schools Established in the United States in the 1980s [9] are Worth Learning: The Teacher Professional Development School is based on the original public primary and secondary schools. It joins the cooperation with the University School of Education to jointly undertake the task of teacher education for normal students and serving primary and secondary school teachers. It is both a research teacher and an education researcher, and its mission is to cultivate better teachers and better schools.

\subsubsection{Teaching and Learning Community in Primary and secondary schools}

Primary and secondary school teachers can't improve their academic level of teaching by themselves, but need to give full play to the role of teaching and research offices and open, constructive and supportive cooperation among teachers. Educational research experts and scholars in local colleges and universities guide the construction of teaching and learning communities in primary and secondary schools through the platform of production, education and research, Carrying out teaching reform and curriculum construction together with seminar methods to form a series of teaching reform achievements: excellent courses, excellent teaching materials, open video courses, etc., in order to declare teaching achievement awards, famous teachers, and rookies in the teaching field.

\subsection{Local colleges and primary and secondary schools cooperate to build a famous teacher studio}

According to the "Strategic Framework Cooperation Agreement", local colleges and universities actively connect primary and secondary schools; explore the establishment of famous teacher studios in accordance with the principles of openness, diversity, collaboration, innovation and integration, and give full play to the role of primary and secondary teachers and excellent teachers in the training of excellent

teachers effect.

Teacher workshops for teachers' professional education to develop professional cognition, new should be made known to the new students learned the value of the industry, target, employment and wages, more want to master specialty courses, new training key, core ability, etc., to understand new area should combine their own experience of basic education present situation, development trend and the growth path and the regularity of basic education teacher, etc.

The teacher's studio implements the triple management of local colleges, municipal education bureaus, and primary and secondary schools. Local colleges and universities are responsible for the management system of the teacher 's studio, the formulation of work responsibilities, the allocation of work funds for the teacher 's studio, the placement of office conditions for the teacher 's studio, and the work of teachers Offices, colleges and universities, education experts, the annual assessment system of famous teachers' studios, etc.; the municipal and county education bureaus, primary and secondary schools are responsible for the formulation of management methods for famous teachers, 
cultivation of famous teachers, selection and recommendation of famous teachers, etc. Each teacher major should set up a famous teacher's studio, whose members include 1-2 college education experts, 1 city and county education bureau teaching and research staff, and 5-7 famous teachers. The responsibilities of a teacher's studio include the following four aspects.

4.4.1 Cognitive education guidance for freshmen in normal school

The teacher's studio should carry out professional cognitive education for freshmen of normal majors, not only to let freshmen know the value, goals, employment and salary of the majors they learn, but also to let freshmen grasp the curriculum settings, training priorities and core competencies of the majors In addition, and we should combine our own experience to let freshmen understand the current status and development trend of regional basic education, as well as the growth path and laws of famous teachers in basic education.

4.4.2 Educational practice guidance for curriculum teaching and graduation design for normal students Teachers' studios should actively participate in the reform and practice of teacher education, including professional development planning, personnel training program revision, professional textbook development, curriculum setting and teaching, internship training, graduation design, professional certification and other guidance work to promote the integration of primary and secondary school needs Talent training links to improve the quality of teacher education professionals.

4.4.3 Subject Research and Educational Reform and Innovation Practice

Subject research is an effective way to realize the combination of theory and practice, and an important means to push practical work to a new height. The famous teacher's studio should combine the problems existing in the training of professional talents in local colleges and universities with the problems in the educational practice of primary and secondary schools, carrying out research on the subject together with teachers of normal schools, putting forward educational reform practice plans, and writing educational reform research papers. High-quality research results not only enhance the influence of famous teacher studios, but also promote the professional development of teacher teachers.

4.4.4 Colonel diagnosis and education practice guidance

The well-known teacher's studio should go to the Industry-university-research base for teachers and educational practice base for on-site diagnosis, and cooperate with the school to customize the diagnosis plan and improvement plan. Teaching contemporary advanced educational ideas, management wisdom and school management experience, to promote schools to improve the level and quality of education and teaching through listening to lectures, lectures, seminars, etc.

\section{Acknowledgement}

This paper is funded by research project on Research on the Operational Mechanism of Dual Tutors for Teacher Education in Local Colleges and Universities [2020JG YB265, Xiangjiaotong [2020] No. 216]; 2020 Hunan Province General University Teaching Reform Research Project: Reform of the Talent Training Model for Excellent Teacher Students in Local Universities [HNJG-2020-0913, Xiang Jiao Tong [2020] No. 232]; 2020 Xiangnan College Educational Reform Project: Research on the Teaching of Pedagogy Courses in Local Colleges and Universities under the Background of Teacher Professional Certification.

\section{Reference}

[1] G Q Chen, X Zhang, Y P Wu. Exploration on the cultivation of excellent teachers in local colleges and universities based on ability training. Chinese Journal of Education, vol. S2, pp. 1-2, 2015.

[2] L Lu. "Return" of a provincial teacher education college. China Education News, 2019-4-25, 04 edition.

ISSN: 0010-8189 
[3] Five departments including the Ministry of Education. Action Plan for Teacher Education Promotion (2018-2022). Teacher [2018] No. 2, 2018-02-11.

[4] Ministry of Education. Opinions on the Implementation of Excellent Teacher Training Program 2.0. Teacher [2018] No. 13, 2018-09-17.

[5] G M Wang, W Huang, L B Wu. Core literacy and ability to promote professional development of teachers [N]. China Education Daily, 2019-04-25, Education Science 07 edition.

[6] G Q Chen, X Zhang, Y P Wu. Exploration on the cultivation of excellent teachers in local colleges and universities based on ability training. Journal of the chinese society of education, vol. S2, pp. 1-2, 2015.

[7] Notice of the General Office of the Ministry of Education on promulgating the reform project of outstanding teacher training plan. http://www.moe.gov.cn/ srcsite/A10/s7011/201412/t20141209_182218.html.2014.12-0

[8] L J Pang, X M Hong. Cracking the Teacher Education Difficulties: Government, University and Primary and Secondary School Cooperation. Journal of Shenyang Normal University (Social Science Edition), vol. 2, pp. 1-3, 2011.

[9] T Zhang. Teacher Professional Development School_ A New Momentum for Teacher Professional Development in the United States. Educational Research, vol. 4, PP. 29, 2007. 